\title{
Changes in Susceptibility to Brown Rot with Ripening in Three Clingstone Peach Genotypes
}

\author{
T.M. Gradziel \\ Department of Pomology, University of California, Davis, CA, 95616 \\ Additional index words. calorimetry, Monilinia fructicola, precocity, Prunus persica
}

\begin{abstract}
Susceptibility to brown rot, caused by Monilinia fructicola (Wint.) Honey, changed with fruit ripening in the susceptible clingstone peach [Prunus persica (L.) Batsch] cultivar Corona and two moderately resistant genotypes. Nonwounded fruit were more resistant before epidermis color break from green to yellow. Susceptibility increased from color break to the period when the epidermis had acquired a uniformly yellow ground color. With continued ripening, susceptibility remained constant or decreased, depending on genotype. A ripeness index based on fruit color permitted objective within and between genotype comparisons of susceptibility. The genetic selection for precociously developing high yellow-orange flesh color has resulted in a clingstone peach selection possessing a flesh quality suitable for processing and with high levels of brown-rot resistance at the mature-green fruit development stage.
\end{abstract}

The control of fruit brown rot is critical to the production of stone fruit and almonds in California. Estimates for the combined costs of prevention and crop losses exceed $\$ 50$ million a year (Ogawa et al., 1985). Monilinia fructicola is the most important brown-rot pathogen that causes pre- and postharvest fruit rot on stone fruit and hull rot on almonds (Ogawa and English, 1991). Susceptibility of freestone peach to infection by this pathogen has been shown to change during fruit growth (Biggs and Northover, 1988a). Developing fruit are initially highly susceptible, become resistant near the time of pit hardening, and later lose this resistance at ripening. The elevated resistance of green stone fruit up to color break has been documented well (Fuleki and Cook, 1976; Hall, 197 1; Jenkins and Reinganum, 1965; Valleau, 1915). The specific timing and nature of the subsequent loss of resistance with ripening remain unclear.

Virtually all previous fruit-rot research with peach has studied the freestone or fresh-market peach. In the ripening freestone peach, the disintegration of the mesocarp's cellular and intercellular matrix results in rapid tissue softening and oxidation of apoplastic substrates. Analogous changes in the hypodermal layer lead to partial skin detachment (Ben-Aire and Sonego, 1980). The different cell and cell-wall properties of clingstone or nonmelting peaches result in greater tissue integrity at the fully ripe stage (Presley et al., 1971; Reeve, 1959). The significance of these textural differences to brown-rot susceptibility has not been studied. A lower incidence of infection and reduced fungal growth rate has been reported in plum (Prunus domestics L.) (Valleau, 1915) and freestone peach (Reinganum, 1964) genotypes with firmer flesh.

The fresh-market freestone peach industry benefits from brownrot resistance at the green-fruit stage because fruit are picked at the mature-green stage to secure harvest firmness. Clingstone fruit for processing are picked at the fully ripe stage; thus, frequent and heavy field losses occur (Ogawa and English, 1991).

The fungicides benzimidazole and dicarboximide and sanitation practices have controlled disease in the past. The identification of Monilinia spp. isolates tolerant to benzimidazole (Tate and Corbin, 1978) and dicarboximides (Elmer and Grant, 1988) and the reduced availability of new fungicides for tree crops due to costly registration requirements have made alternative disease-

Received for publication 3 June 1992. Accepted for publication 19 May 1993. The cost of publishing this paper was defrayed in part by the payment of page charges. Under postal regulations, this paper therefore must be hereby marked advertisement solely to indicate this fact. control strategies necessary. Such strategies include developing brown-rot-resistant cultivars, biological control, and inducing host resistance (Ogawa et al., 1985).

Improved levels of brown-rot resistance have been identified in the Brazilian clingstone peach 'Bolinha' (Feliciano et al., 1987). A green to yellow-green epidermis and flesh color and a high rate of preharvest fruit drop have limited commercial acceptance of California selections developed from this germplasm. Progeny from controlled crosses to 'Bolinha' seem to inherit high levels of disease resistance and the tendency for preharvest drop, green fruit color, and susceptibility to bruising (Gradziel and Wang, 1993). The present research was initiated to 1) separate any distinct fully ripe fruit resistance from the transitory green-fruit resistance and 2) uncouple, developmentally, the epidermal maturation from flesh maturation to develop cultivars possessing a highly colored, good-processing-quality flesh with a green and more resistant epidermis. This paper reports on the changes in susceptibility to brown rot with ripening for the susceptible clingstone peach 'Corona', a seedling selection of the resistant cultivar Bolinha, and an advanced breeding line demonstrating precocious flesh pigmentation.

\section{Materials and Methods}

Plant materials. 'Corona' and two clingstone breeding lines Bolinha-261 and UC 18-8-23 were tested in 1990 and 1991. 'Corona' is the latest-maturing cultivar in commercial plantings and is highly susceptible to brown rot. Bolinha-261, an open-pollinated seedling of the resistant Brazilian 'Bolinha', was selected for a similar late-ripening period and improved fruit color. UC 18-8-23 is an open-pollinated seedling derived from crosses of Californian to South African and Australian germplasm and also matures equally late. UC 18-8-23 was selected for its ability to develop yellow-orange flesh color precociously up to 2 weeks before epidermis color break from green to yellow. All fruit were harvested from adjacently planted 10-year-old trees located in an experimental orchard in Winters, Calif. Fungicides were not applied to this orchard, which was otherwise managed in a standard manner. Fruit were hand-harvested to single-layered, cupped plastic packing trays and held at $22 \mathrm{C}$ for at least $12 \mathrm{~h}$ to dissipate field heat.

Fruit inoculation and disease severity rating. M. fructicola isolates sensitive to methyl\{ 1 -[( butylamino)carbonyl]- $1 \mathrm{H}$ benzimidazol-2-yl \}carbarnate (benomyl) were obtained from J.M. 
Ogawa, Univ. of California, Davis. Conidial suspensions were obtained by washing 5- to 7-day-old potato dextrose agar cultures with $20 \mathrm{ml}$ sterile distilled water containing $0.01 \%$ Tween 20 as a wetting agent. The inoculum was filtered through four layers of sterile cheesecloth to minimize the presence of mycelial fragments and adjusted to a concentration of $2 \times 10^{4}$ conidia $/ \mathrm{ml}$. Conidial suspension $(10 \mu \mathrm{l})$ was deposited to the more-mature cheek surface. Ten-fruit samples for each ripeness stage and for each genotype were inoculated and evaluated in 1990. At least 16 fruit per ripeness stage for each genotype were inoculated and evaluated in 1991. The inoculation site was previously determined to be free of visible injury by examination with a stereomicroscope. In 1990, five additional fruit per ripeness stage for each genotype were inoculated similarly but into exposed fruit flesh after a 6-mm-deep section of epidermis and flesh had been removed. All inoculated fruit were incubated for $72 \mathrm{~h}$ at 22 to $25 \mathrm{C}$ in darkness at $\approx 95 \%$ relative humidity $(\mathrm{RH})$. $\mathrm{RH}$ was maintained by placing the fruit on plastic supports in plastic containers holding sterile cheesecloth soaked in sterile distilled water. Lesion diameter was recorded at $72 \mathrm{~h}$ in 1990 and at 48 and $72 \mathrm{~h}$ in 1991.

1990 Fruit ripeness classification. Fruit were classified into the four ripeness stages developed by Leonard et al. (1961). The four stages are determined by overall ground color: $\mathrm{M}-\mathrm{I}=$ predominantly green with some yellow, M-II = predominantly yellow with some lingering green, M-III = yellow, and M-IV= yellow-orange. Ground color was defined as the epidermis color exclusive of red anthocyanin pigmentation (fruit blush).

Following the 72-h disease reading, the flesh on the opposite cheek of the fruit was sliced away to a depth of $6 \mathrm{~mm}$ and flesh color was assessed against a California Dept. of Food and Agriculture (CDFA) no. 2 minimum flesh color disk for processing-peach acceptability.

1991 Fruit ripeness classification. Epidermis-ground color, as characterized by the Commission Internationale de L'Eclairage (CIE) (1978) $a^{*}$ color value of the L*a*b* color space, was used as a ripeness index. Ground color $\mathrm{a}^{*}$ value for a 3 -cm-diameter disk centered on the site of subsequent testing was measured using a spectrophotometer (Colormet; Agtron, Reno, Nev.). This equipment used a $45^{\circ}$ diametrically opposed illumination with a $3 \mathrm{~cm}$ viewing area and was calibrated to a white porcelain reference plate $\left[\mathrm{L}^{*} .=94.5, \mathrm{a}^{*}=(-1.0), \mathrm{b}^{*}=0.0\right]$. Flesh $\mathrm{a}^{*}$ color, when evaluated, was measured after a 6-mm-deep section of epidermis and flesh was removed from the more-mature fruit cheek. Epidermis ground color was measured at the site of subsequent testing for all fruit quality and disease evaluations. Flesh measurements were limited to fruit quality evaluations.

CIE a*color values for fruit flesh color and the pass or fail score after testing fruit flesh against the CDFA no. 2 minimum color disk were obtained from Tri-Valley Growers (Modesto, Calif.) for more than 1600 fruit samples from the mid- to late-season 1991 clingstone peach harvest. This information was separated into two subpopulations based on CDFA no. 2 disk results-pass or fail. Population means and SDS were calculated and the upper 95\% confidence limit of the fail population was selected as the threshold value for desirable flesh a* color value. The Tri-Valley data, which represent the ripeness range typically encountered in a commercial harvest, were used to set $a^{*}$ value limits for 1991 fruit evaluations. Fruit ripeness stages consisted of five equally spaced six-unit intervals with ground color $\mathrm{a}^{*}$ values ranging from -3 to 27 and with median values of $0,6,12,18$, and 24 . The minimum value of -3 approximates the threshold value below which postharvest ripening will not continue in freestone peach (Delwiche and Baumgardner, 1983).
An additional 12 fruit for each ripeness stage for each genotype were also evaluated at the site, where epidermis color was measured for fruit quality characteristics including flesh color, flesh $\mathrm{pH}$ at $6 \mathrm{~mm}$ deep [using a model V- 1208 flat surface probe with a constant 1.5-N application force and a model $80 \mathrm{pH}$ meter (Markson)], flesh firmness at $6 \mathrm{~mm}$ deep (measured with a Magness-Taylor firmness tester with an 8-mm flat tip), and soluble solids concentration (SSC) of juice from the 6-mm-thick section of flesh and epidermis tissue (measured as percentage Brix using a hand refractometer). Fruit of each genotype were also ranked in increasing order of ripeness by visually assessing overall ground color.

\section{Results}

The lowest susceptibility levels were observed in ripeness stage M-I (about color break) for nonwounded fruit of all genotypes tested in 1990 (Table 1 ). Fully acceptable flesh pigmentation at this stage was present only in UC 18-8-23. Susceptibility of nonwounded fruit increased from ripeness stages M-I to M-III. Fruit susceptibility decreased by $\approx 20 \%$ in stage M-IV for 'Corona' and UC 18-8-23. High fruit abscission in stages M-I and M-II for Bolinha-261 resulted in an insufficient number of fruit meeting the groundcolor criteria for the final ripeness stage. UC 18-8-23 and Bolinha-261 had significantly smaller lesions than 'Corona' at each ripeness stage ( $P \leq 0.05$, Tukey's ranking not shown).

Wounded fruit of all genotypes and ripeness stages developed lesions with diameter means of $>30 \mathrm{~mm} 72 \mathrm{~h}$ after inoculation. No significant differences were observed either within ripeness stages or between genotypes.

The relative susceptibility of nonwounded fruit $72 \mathrm{~h}$ after inoculation in 1991 (Table 2) was similar to that for 1990 (Table 1). A good correlation was observed between fruit epidermis ripeness stages based on visual scoring and CIE a* values determined calorimetrically ( $r=0.81$ for 'Corona' data).

Average 1991 lesion size $72 \mathrm{~h}$ after inoculation was lowest for the most immature fruit (Table 2). Lesion size increased with ripening in 'Corona', stabilized at middle $\mathrm{a}^{*}$ values, then significantly decreased by $\approx 20 \%$ in the final ripeness stage, as in the 1990 performance. Mean lesion size increased rapidly with increasing ripeness with Bolinha-261 and UC 18-8-23, but was not smaller in

Table 1. Sample means for brown-rot lesion diameter $(\mathrm{mm})$ and flesh color acceptability $72 \mathrm{~h}$ after controlled inoculation of clingstone peaches at four ripeness stages for three genotypes evaluated in 1990 .

\begin{tabular}{lccccc}
\hline & & \multicolumn{4}{c}{ Ripeness stage } \\
\cline { 3 - 6 } Genotype & Measurement & M-I & M-II & M-III & M-IV \\
\hline Corona & Mean $^{2}$ & $29 \mathrm{a}$ & $42 \mathrm{~b}$ & $51 \mathrm{c}$ & $40 \mathrm{~b}$ \\
& STD $^{\mathrm{y}}$ & 6 & 7 & 5 & 10 \\
UC18-8-23 & Pass $^{\mathrm{x}}$ & 0.3 & 0.9 & 1.0 & 1.0 \\
& Mean & $1 \mathrm{a}$ & $16 \mathrm{~b}$ & $29 \mathrm{c}$ & $23 \mathrm{bc}$ \\
& STD & 2 & 15 & 9 & 9 \\
Bolinha-261 & Pass & 1.0 & 1.0 & 1.0 & 1.0 \\
& Mean & $3 \mathrm{a}$ & $11 \mathrm{a}$ & $23 \mathrm{~b}$ & $---{ }^{w}$ \\
& STD & 7 & 12 & 9 & --- \\
& Pass & 0.2 & 0.7 & 1.0 & --- \\
\hline
\end{tabular}

${ }^{\mathrm{z}}$ Mean separation within rows by Tukey's studentized range test at $P \leq$ 0.05 .

${ }^{\mathrm{y}} \mathrm{STD}=$ sample standard deviation.

${ }^{\mathrm{x}}$ Pass $=$ proportion of sample with flesh color exceeding California Dept. of Food and Agriculture no. 2 color disk.

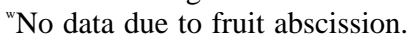


Table 2. Sample means and SDS (in parenthesis) for fruit quality and brown-rot lesion diameter at five ripeness stages in clingstone peach genotypes evaluated in 1991.2

\begin{tabular}{|c|c|c|c|c|c|c|}
\hline \multirow[b]{2}{*}{ Measurement } & \multirow[b]{2}{*}{ Genotype } & \multicolumn{5}{|c|}{ Ripeness index ${ }^{y}$} \\
\hline & & 0 & 6 & 12 & 18 & 24 \\
\hline \multirow[t]{3}{*}{ Lesion diameter $(\mathrm{mm}), 48 \mathrm{~h}$} & Corona & $5(1) \mathrm{a}$ & $8(2) a b$ & $7(3) a b$ & $8(2) a$ & $5(1) b$ \\
\hline & UC18-8-23 & $1(2) \mathrm{a}$ & $1(2) \mathrm{a}$ & $2(2) \mathrm{a}$ & $2(2) a$ & $2(3) a$ \\
\hline & Bolinha-261 & $1(1) \mathrm{a}$ & $3(4) \mathrm{ab}$ & $5(3) b$ & & \\
\hline \multirow{3}{*}{ Lesion diameter $(\mathrm{mm}), 72 \mathrm{~h}$} & Corona & $21(5) \mathrm{a}$ & $29(5) b$ & $27(5) b$ & $26(3) b$ & $19(5) \mathrm{a}$ \\
\hline & UC18-8-23 & $5(9) \mathrm{a}$ & $9(8) a b$ & $13(9) \mathrm{ab}$ & $16(7) b$ & $15(7) b$ \\
\hline & Bolinha-261 & $8(5) \mathrm{a}$ & $12(10) a b$ & $16(8) b$ & & \\
\hline \multirow[t]{3}{*}{ Soluble solids concn (\% Brix) } & Corona & $10.5(1.4) \mathrm{a}$ & $10.6(1.1) \mathrm{a}$ & $11.7(1.8) \mathrm{ab}$ & $13.2(2.0) \mathrm{b}$ & $13.7(1.4) \mathrm{b}$ \\
\hline & UC18-8-23 & $10.0(1.3) \mathrm{a}$ & $9.9(1.3) \mathrm{a}$ & $10.2(1.7) \mathrm{ab}$ & $11.6(1.8) \mathrm{b}$ & $13.4(1.9) \mathrm{c}$ \\
\hline & Bolinha-261 & $13.8(1.7) \mathrm{a}$ & $12.9(0.8) \mathrm{a}$ & $13.1(1.0) \mathrm{a}$ & & \\
\hline \multirow[t]{3}{*}{$\mathrm{pH}$} & Corona & $3.9(0.1) \mathrm{ab}$ & $3.8(0.1) \mathrm{a}$ & $3.9(0.2) \mathrm{b}$ & $3.9(0.1) b$ & $4.1(0.2) \mathrm{c}$ \\
\hline & UC $18-8-23$ & $3.9(0.2) \mathrm{a}$ & $3.9(0.2) \mathrm{a}$ & $3.9(0.1) \mathrm{a}$ & $4.1(0.1) b$ & $4.1(0.1) b$ \\
\hline & Bolinha-261 & $3.9(0.2) \mathrm{a}$ & $3.8(0.1) \mathrm{a}$ & $3.7(0.7) \mathrm{a}$ & & \\
\hline \multirow[t]{3}{*}{ Firmness (N) } & Corona & $2.8(0.3) \mathrm{a}$ & $2.4(0.2) \mathrm{a}$ & $2.2(0.4) \mathrm{ab}$ & $1.9(0.7)$ b-" & $1.8(0.6) \mathrm{b}$ \\
\hline & UC18-8-23 & $2.3(0.2) \mathrm{a}$ & $1.6(0.2) b$ & $1.3(0.3) b c$ & $1.2(0.4) \mathrm{c}$ & $1.2(0.3) \mathrm{c}$ \\
\hline & Bolinha-261 & $2.1(0.6) \mathrm{a}$ & $1.1(0.5) b$ & $0.7(0.8) \mathrm{b}$ & & \\
\hline \multirow[t]{3}{*}{ Flesh color ${ }^{x}$} & Corona & $5.6(1.8) \mathrm{a}$ & $8.8(2.1) b$ & 12.7 (2.6) C & $17.9(1.8) \mathrm{d}$ & $20.4(2.3) \mathrm{e}$ \\
\hline & UC18-8-23 & $14.3(1.4) \mathrm{a}$ & $18.8(1.5) \mathrm{b}$ & $23.0(1.2) \mathrm{C}$ & $24.3(1.7) \mathrm{C}$ & $23.4(1.5) \mathrm{C}$ \\
\hline & Bolinha-261 & $4.2(3.4) \mathrm{a}$ & $10.4(1.9) b$ & $13.8(1.4) \mathrm{C}$ & & \\
\hline
\end{tabular}

${ }^{\overline{2}}$ Mean separation within rows by Tukey's studentized range test at $P \leq 0.05$.

'Ripeness index is the Commission International de L'Eclairage (CIE) $a^{*}$ value of fruit epidermis ground color at the evaluation site.

${ }^{x}$ Flesh color characterized by its mean CIE a* color score.

most-mature fruit than in less-mature fruit.

The relative resistance among genotypes varied with ripeness stage as with 1990 findings. UC 18-8-23 again had significantly smaller lesions after $72 \mathrm{~h}$ than 'Corona' at all ripeness stages tested, while Bolinha-261 lesions were significantly smaller only at the first two of the three intervals tested $(P \leq 0.05$, Tukey's ranking not shown). Lesion size $48 \mathrm{~h}$ after inoculation showed similar although less significant changes. Greater resistance was observed in the green to color-break fruit, with an increase in susceptibility with ripening. Significantly smaller lesions at the final ripeness stage were detected only in 'Corona'.

Small within-genotype changes were observed for $\mathrm{pH}$ and SSC over the 1991 ripening period, with significant changes observed only at the final ripeness stages (Table 2). Larger and significant within-genotype changes occurred for loss of fruit firmness and increase in flesh color, (Table 2, Fig. 1).

Flesh a* color value was highly correlated with ground a* color value in 'Corona', and somewhat less so for Bolinha-261 ( $r=0.97$ and 0.93 , respectively). A lower correlation ( $r=0.60)$ was observed between flesh and ground color a* values for UC 18-8-23 because of an apparent stabilization of flesh color in the more mature fruit. A flesh $a^{*}$ value threshold of 10.0 was desirable to ensure confidence ( $P$ 0.05) against failure of CDFA no. 2 minimum color disk. Flesh color was not adequate until the second or third ripeness stage for 'Corona' and Bolinha-261. 'Corona' possessed desirable flesh color when its flesh firmness was between 3 and $5 \mathrm{~N}$, which is within the preferred range for processing. UC18-8-23 possessed adequate flesh color and firmness during all ripeness stages examined. High rates of preharvest fruit drop and low flesh firmness were characteristic of Bolinha-261.

\section{Discussion}

Calorimetric analysis in 1991 allowed a more objective and reliable classification of fruit epidermis and flesh color change and provided a more precise color characterization at the testing site, particularly for horticulturally marginal material such as Bolinha-261. The epidermis seems to be the site of brown-rot resistance in this peach; therefore, the use of an epidermis-based ripeness index is appropriate. Previous studies have identified the $\mathrm{a}^{*}$ color value of freestone peach ground color as one of the most effective indicators of fruit ripeness (Delwiche and Baumgardner, 1983, 1985; Meredith et al., 1989). Changes in important clingstone fruit quality characteristics relative to the epidermis $a^{*}$ value (Table 2, Fig. 1) agree with reported changes in these characteristics when other established ripening indexes are used (Kader et al., 1982).

The efficacy of the ground color a* value as a ripeness index in clingstone peach is further demonstrated by its high correlation with the flesh $a^{*}$ value. Flesh $a^{*}$ value is the principal ripeness index used by the processing peach industry (Kader, 1980), as it has been shown to be a very good predictor of processed color (Fuleki and Cook, 1976; Kader et al., 1982; Leonard et al., 1961).

Fruit flesh of all genotypes and ripeness stages tested were highly susceptible to brown rot. This susceptibility is demonstrated by the uniformly high rates of lesion development observed in 1990 when wounded flesh was inoculated. Similarly, in 1991, while lesion development on nonwounded fruit during the first 48 $\mathrm{h}$ after inoculation varied considerably depending on genotype and degree of ripeness, the relative change in lesion size over the next $24 \mathrm{~h}$ was relatively uniform. Feliciano et al. (1987) reported a similarly high susceptibility of clingstone peach flesh in wounded samples of the Brazilian cultivars Conserva-144 and Bolinha, although the lesion expansion rate was statistically smaller in 'Bolinha'.

Some resistance was present in 'Bolinha' when uninjured fruit were inoculated. The epidermis has been identified as the tissue primarily responsible for this resistance (Adaskaveg et al., 1989, 1991) and has been characterized as possessing a thicker cuticle, a more compact cell type, and fewer trichomes than in nonresistant types. A high incidence of preharvest fruit drop and poor fruit color, however, has prevented commercial plantings of this gerrn- 

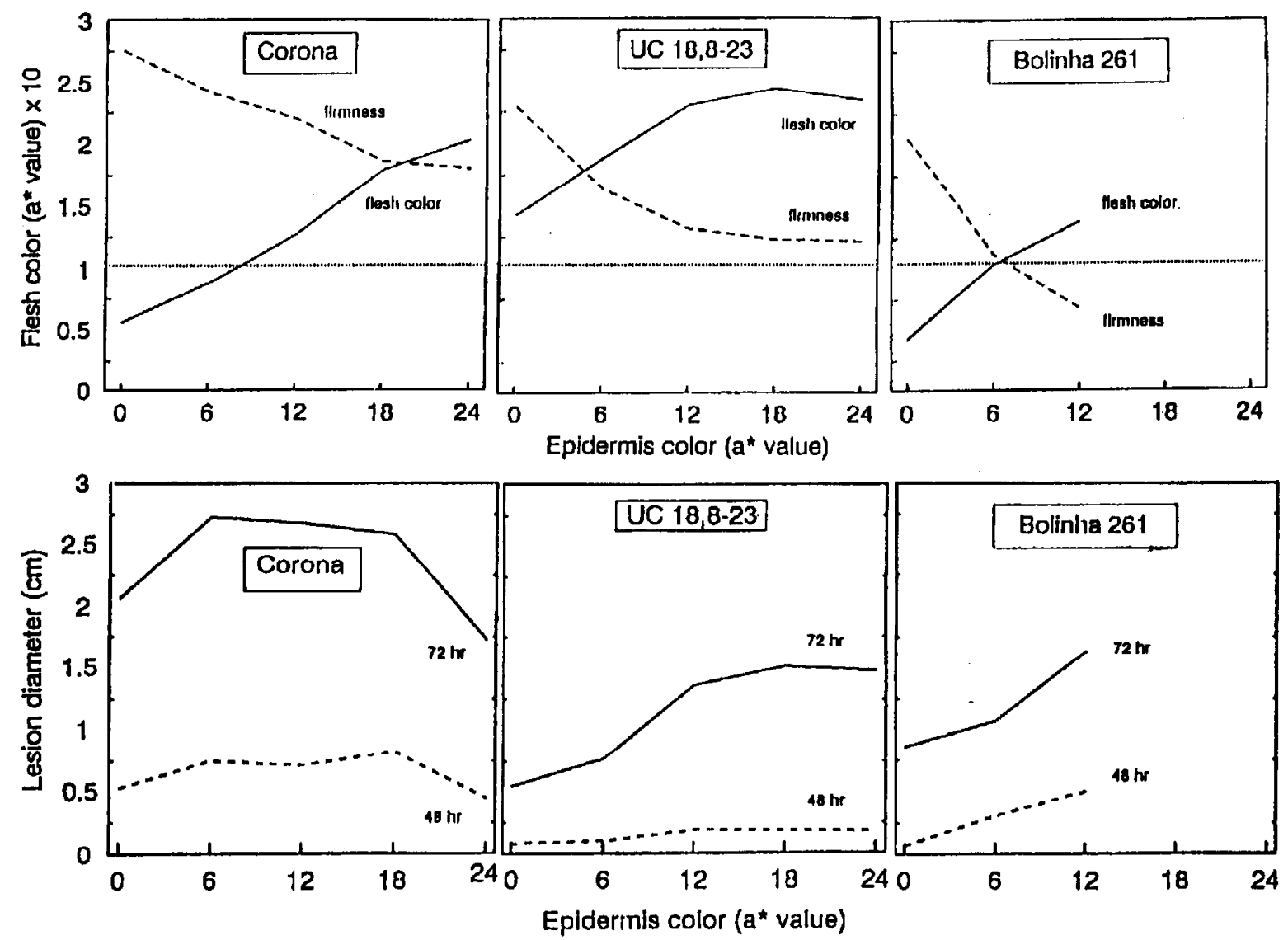

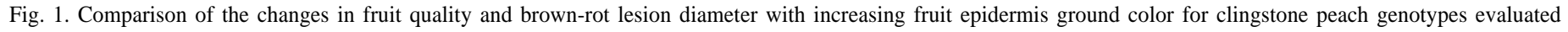

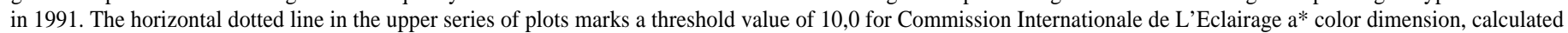

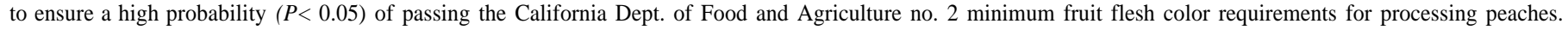

plasm. Using ground-color standards in 1990 showed that fruit at the most-mature ripeness stage were lacking. The more objective calorimetric analysis in 1991 demonstrated that part of the perceived resistance of this genotype resulted from sampling predominantly immature and, therefore, inherently less-susceptible tissue. Evaluations of more advanced 'Bolinha' derived seedlings have identified resistant genotypes superior to UC 18-8-23 at full fruit ripeness (Gradziel and Wang, 1993).

The reduced susceptibility observed in the most-ripe stage of 'Corona' fruit corresponds to the period during which changes in quality characteristics of overripe fruit begin to appear. In addition to better flesh color, higher SSC, and reduced firmness (Table 2), overripe characteristics include the development of off-flavors, resulting in part from the oxidation of intercellular, substances including volatiles (Spencer et al., 1978), and the development of a tissue woolliness brought about by the partial breakdown of the intracellular tissue matrix (Ben-Aire and Sonego, 1980). Previous work has shown that the susceptibility of freestone peaches to $M$. fructicola is associated with differences in fruit structure (Curtis, 1928; Hall, 197 1; Reinganum, 1964) and chemical inhibitors, including phenolic and volatile compounds (Wilson et al., 1987). A change in susceptibility at this stage is thus reasonable. Hall (1972) concluded that tissue firmness and chemical inhibitors seem to be the major factors limiting lesion expansion in mature-green freestone peach fruit flesh. At the fully ripe stage, lesion expansion became primarily dependent on the rate at which the fungus grows, using nutrients supplied by the fruit. Disease development during the transition from ripe to overripe fruit has not been adequately studied in freestone peach due to the rapid disintegration of flesh integrity at this time,

Lesion development at the fully ripe to overripe stage was not reduced in UC 18-8-23, Bolinha-261, and about half of the 30 additional genotypes screened in this analysis. Chemical and physical components of fruit flesh vary with genotype (Kader et al., 1982; Spencer et al., 1978), Genotype and ripeness differences in disease response are thus presumably mediated by a wide array of physical, chemical, and physiological events.

Including a greater proportion of either underripe or fully to overripe fruit in disease evaluations of genotypes such as 'Corona' would lead to a sizable reduction in overall disease rating similar in consequence to the limited range of ripeness sampled in Bolinha-261. Using a ripeness index that allows within and between genotype standardization is necessary to protect against such sampling bias.

The capability of separating color development in flesh from that in epidermis through genetic selection to exploit the higher levels of resistance of the immature-green epidermis is demonstrated by the overall performance of UC 18-8-23 (Table 2, Fig. 1 ). The range in flesh $\mathrm{pH}, \mathrm{SSC}$, firmness, and flesh color for UC18-8-23 is within acceptable levels for processing, even at the mature-green stage. Processed mature-green UC 18:8-23 fruit have been rated good to very good in sensory panel evaluations in 1990 and 1991 (unpublished data).

Scattered occurrences of rapid lesion development at the early ripeness stages contributed to notably large SDS for lesion size in resistant genotypes. These may represent previously quiescent infections. Quiescent infections, which are initiated at flowering or early fruit development, have been implicated in disease outbreaks 
in green fruit and postharvest losses in freestone peach (Jenkins and Reinganum, 1965; Ogawa et al., 1985; Tate and Corbin, 1978). Quiescent infection rates of up to $77 \%$ of harvested fruit have been reported by Rosenberger (1985) in plum. Since quiescent infections may have penetrated the epidermis before becoming quiescent, they may be unaffected by an epidermis-limited resistance. Thus, the importance of resistance mechanisms limited to the fruit epidermis, including changes in susceptibility with ripening, depend largely on postharvest management. Where the fruit is processed rapidly after harvest, the major risk for disease development occurs in the field. Hall $(1971,1972)$ has shown that $M$. fructicola conidia germination and hyphae penetration of the epidermis is the primary rate-controlling process in disease development on intact fruit. When fruit are stored for $24 \mathrm{~h}$ or more before processing, direct fruit-to-fruit spread will probably become the limiting factor in disease development (Manji and Ogawa, 1985). Environmental conditions within the fruit bins and the greater probability of open wounds and high inoculum density (both as conidia and infective hyphae) would create high disease pressures (Biggs and Northover, 1988b; Hall, 1971) and probably easily overcome even high levels of epidermis-based resistance. An understanding of physiological and management processes is therefore necessary for selecting genotypes with stable resistance.

\section{Literature Cited}

Adaskaveg, J. E., A.J. Feliciano, and J.M. Ogawa. 1989. Comparative studies of resistance in peach genotypes to Monilinia fructicola. Phytopathology 79:1183-1184. (Abstr.)

Adaskaveg, J.E., A.J. Feliciano, and J.M. Ogawa. 1991. Evaluation of the cuticle as a barrier to penetration by Monilinia fructicola. Phytopathology 81:1150. (Abstr.)

Ben-Aire, R. and L. Sonego. 1980. Pectolytic enzyme activity involved in wooly breakdown of stored peaches. Photochemistry 19:2553-2555.

Biggs, A.R. and J. Northover. 1988a. Early and late-season susceptibility of peach fruits to Monilinia fructicola. Plant Dis. 72:1070-1074.

Biggs, A.R. and J. Northover. 1988b. Influence of temperature and wetness duration on infection of peach and sweet cherry fruits by Monilinia fructicola. Phytopathology 78:1352-1353.

Commission Internationale de L'Eclairage. 1978. Recommendations on uniform color spaces, color-difference equations and psychometric color terms. Bureau Central de la Commission Internationale de L'Eclairage, Paris. Ser. Publ. CIE 15. Suppl. 2.

Curtis, K.M. 1928. The morphological aspect of resistance to brown rot in stone fruit. Ann. Bot. (London) 42:39-68.

Delwiche, M.J. and R.A. Baumgardner. 1983. Ground color measurements of peaches. J. Amer. Soc. Hort. Sci. 108:1012-1016.

Delwiche, M.J. and R.A. Baumgardner. 1985. Ground color as a peach maturity index. J. Amer. Soc. Hort. Sci. 110:53-57.

Elmer, P.A.G. and R.E. Grant. 1988. Spatial distribution, fitness and survival of dicarboximide resistant strains of Monilinia fructicola. 5th Intl. Congr. of Plant Pathol., Kyoto, Japan. p. 20-27, 310 (Abstr.).

Feliciano, A., A.J. Feliciano, and J.M. Ogawa. 1987. Monilinia fructicola resistance in peach cultivar Bolinha. Phytopathology 77:776-780.
Fuleki, T. and F.I. Cook. 1976. Relationship of maturity as indicated by flesh color to quality of canned clingstone peaches. Can. Inst. Food Sci. Technol. J. 9(1):43-46.

Gradziel, T.M. and D. Wang. 1993. Evaluation of brown rot resistance and its relation to enzymatic browning in clingstone peach. J. Amer. Sot. Hort. Sci. 118:675-679.

Hall, R. 1971. Pathogenicity of Monilinia fructicola. II. Penetration of peach leaf and fruit. Phytopathol. Z. 72:281-290.

Hall, R. 1972. Pathogenicity of Monilinia fructicola. III. Factors influencing lesion expansion. Phytopathol. Z. 73:27-38.

Jenkins, P.T., and C. Reinganum. 1965. The occurrence of quiescent infection of stone fruits caused by Sclerotinia fructicola (Wint.) Rehm. Austral J. Agr. Res. 16:131-140.

Kader, A. 1980. Brown discoloration of clingstone peaches. Cling Peach Quarterly 16(1):12-13.

Kader, A.A., C.M. Heintz, and A. Chordas. 1982. Postharvest quality of fresh and canned clingstone peaches as influenced by genotypes and maturity at harvest. J. Amer. Soc. Hort. Sci. 107:947-951.

Leonard, S.J., B.S. Luh, C.O. Chichester, and M. Simone. 1961. Relationship of fresh clingstone peach color to color and grade after canning. Food Technol. 15:492-494.

Manji, B.T. and J.M. Ogawa. 1985. Quiescent infections and disease control in the shipping container. Proc. 44th Annu. Convention Natl. Peach Council (Nashville). p. 23-24.

Meredith, F.I., J.A. Robertson, and R.J. Horvat. 1989. Changes unphysical and chemical parameters associated with quality and postharvest ripening of harvested peaches. J. Agr. Food Chem. 37:1210-1214.

Ogawa, J.M. and H. English. 1991. Diseases of temperate zone tree fruit and nut crops. Univ. of Calif., Div. of Agr. and Natural Resources, Oakland, Calif. Publ. 3345.

Ogawa, J.M., B.T. Manji, and R.M. Sonoda. 1985. Management of the brown rot disease on stone fruits and almonds in California, p. 8-15. In: T.J. Burr (cd.). Proceedings of brown rot of stone fruit workshop. New York State Agr. Expt. Sta., Geneva.

Presley, R., D.M. Hinton, and J.K. Avants. 1971. Development of polygalacturonase activity and solubilization of pectin in peaches during ripening. J. Food. Sci. 36:1070-1073.

Reeve, R.M. 1959. Histological and histochemical changes in developing and ripening peaches. II. The cell walls and pectins, Amer. J. Bet. 46:210-217.

Reinganum, C. 1964. Pectolytic enzyme production by Sclerotinia fructicola (Wint.) Rehm, and its role in the pathogenesis of stone fruits. Austral. J. Biol. Sci. 17:705-718.

Rosenberger, D.A. 1985. Observations on quiescent brown rot infections in grand prize plums, p. 19-22. In: T.J. Burr (cd.). Proceedings of brown rot of stone fruit workshop. New York State Agr. Expt. Sta., Geneva.

Spencer, M.D., R.M. Pangborn, and W.G. Jennings. 1978. Gas chromatographic and sensory analysis of volatiles from cling peaches. J. Agr. Food Chem. 104626-629.

Tate, K.G. and J.B. Corbin. 1978. Quiescent fruit infections of peach, apricot, and plum in New Zealand caused by the brown rot fungus, Sclerotinia fructicola. N.Z. J. Expt. Agr. 6:319-25.

Valleau, W.D. 1915. Varietal resistance of plums to brown rot. J. Agr. Res. (Washington, D.C.) 5:365-396.

Wilson, C. L., J.D. Franklin, and B.E. Otto. 1987. Fruit volatiles inhibitory to Monilinia fructicola and Botrytis cinerea. Plant Dis. 71:316-319. 